\title{
Natural background levels and seasonal influence on groundwater chemistry of the Upper São Francisco karst region, MG, Brazil
}

\author{
Thiago Nogueira Lucon ${ }^{1 *}(\mathbb{D})$, Adivane Terezinha Costa ${ }^{1}$, \\ Paulo Galvão ${ }^{10}$, Mariangela Garcia Praça Leite ${ }^{1}$ (1)
}

\begin{abstract}
Karst aquifers are large water reservoirs that supply approximately 25\% of the world population. They are also extremely sensitive to contamination, demanding knowledge on groundwater quality regarding base level conditions for the main cations and anions. Knowing the Natural Background Level (NBL) values of these waters becomes an indispensable measure to understand aquifers and hydrochemical anomalies, either from anthropogenic or geogenic origin. This paper aimed to provide a hydrochemical characterization and to propose NBL $90 \%$ values for the little-studied groundwater of the São Miguel River watershed, Upper São Francisco River, MG, Brazil. NBL 90\% values were estimated using statistical analyses followed by an analysis of seasonal influence on observed concentrations. The water was classified as calcium bicarbonate, with the highest NBL $90 \%$ values occurring during the rainy season for $\mathrm{Ca}^{2+}, \mathrm{K}^{+}, \mathrm{HCO}_{3}^{-}, \mathrm{SO}_{4}^{2-}, \mathrm{Cl}, \mathrm{NO}_{3}^{-}$, and $\mathrm{As}^{3+}$. On the other hand, $\mathrm{Mg}^{2+}, \mathrm{Na}^{+}, \mathrm{PO}_{4}^{3-}$, and $\mathrm{Zn}^{2+}$ presented reduction in concentration during this season. Nitrate, phosphate and chloride anomalies (values above NBL 90\%) are directly related to human action. Thus, monitoring and proposing NBL 90\% values were an essential tool to help in understanding the hydrochemical behavior of waters in this watershed.
\end{abstract}

KEYWORDS: Natural Background Level; São Miguel watershed; Arcos, Pains; Karst aquifers; Upper Säo Francisco Basin; Brazil.

\section{INTRODUCTION}

Karst systems are considered important underground reservoirs due to their ability to store large amounts of water, which allows the hydric supply of approximately $25 \%$ of the world population (Ford \& Williams 2007). These aquifers are usually the only source of drinking water in karst regions (Kovačič 2003, Ford \& Williams 2007). By 2025, estimates are that $80 \%$ of the world population may require to use water from these regions (Forti 2002). In Brazil, several urban centers use groundwater exclusively or as a complement for water supply. According to the Brazilian Institute of Statistics and Geography (IBGE 2003), 61\% of the Brazilian population is supplied with groundwater. In the state of Maranhão, northeastern Brazil, over 70\% of municipalities are supplied with groundwater, while in the states of São Paulo and Piauí this percentage is as high as $80 \%$ (Brasil 2003). In turn, in the Lagoa Santa karst region (state of Minas Gerais), 100\% of water supply is provided by groundwater (Pessoa \& Loureiro 2005).

The chemical composition of water changes from the moment it enters the system through infiltration of rainwater, river water, and other sources. In karst regions, underground reservoirs present higher vulnerability to contamination due to the difficulty in depuration of waters in the subterraneous environment, which results from the rapid direct percolation from the vadose zone into the phreatic zone (Haddad 2007, Villanueva et al. 2014). Consequently, shallower aquifers rarely reflect real natural concentration levels, while deeper ones may be free from human impacts (Vázquez-Suñé et al. 2005, Müller et al. 2006). The state of groundwater in highly urbanized areas is especially affected by human practices due to agricultural and mining activities, which directly influence water quality parameters (Appelo \& Postma 2005, Fritzsons 2003, Fritzsons et al. 2004, Fritzsons et al. 2009).

1Department of Geology, Universidade Federal de Ouro Preto - Ouro Preto (MG), Brazil. E-mails: thiago.n.lucon@gmail.com, adivanecosta@gmail.com, hidropaulo@gmail.com,mgpleite@gmail.com

*Corresponding author

Manuscript ID: 20180071. Received on: 06/20/2018. Approved on: 10/10/2018. 
Considering the natural complexity of karst landscapes and the availability of waters as an important natural resource, these areas and the aquifers found in them require special protection (Andreo et al. 2006). With this intention, several countries have been using various methods to establish Natural Background Level (NBL) values for the concentration of chemical elements, especially those that present high toxicity. Due to the lack of a specific methodological concept to establish these values, the European community created in 2006 the Background Criteria for the Identification of Groundwater Thresholds (BRIDGE) project, which proposed a new definition of NBL and reference (REF) values for each substance (BRIDGE 2006, 2009).

While the NBL of a given substance, or element, in groundwater may be defined as the range of concentrations derived from the interaction of various natural atmospheric, geologic, chemical, and biological processes during water infiltration and circulation, REF values for each substance are the already existing standards in various legislations (e.g., limits for drinking water) (Ducci \& Sellerino 2012). Natural concentrations and anomalies that may indicate either geogenic or anthropogenic occurrences can only be distinguished by defining NBL values (Hawkes \& Webb 1962, Reinmann et al. 2005, Edmunds \& Shand 2008, Hinsby et al. 2008).

Threshold values (TV) are used to identify anomalous values among a set of samples analyzed. Various methods may be adopted to find TV, since there is no simple value for thresholds, but rather distribution of background values and distribution of values that may be considered as anomalous (Tennant \& White 1959, Hawkes \& Webb 1962, Bolviken 1971). One of the most applied methods to define these anomalies was the graphical method proposed by Lepeltier (1969) and slightly modified by Matschullat et al. (2000). The lowest threshold is obtained in this approach by taking the median value plus two times the standard deviation, while the mean value plus two times the standard deviation results in the highest value (Andriotti 2010).

In South America in general, including Brazil, there are only a few studies focusing on the representation of natural background levels for sensitive waters, such as karsts. In water and sediments of Samborombón Bay, Argentina, Schenone et al. (2007) presented NBL 90\% for trace metals ( $\mathrm{As}^{3+}, \mathrm{Cd}$, $\mathrm{Cr}, \mathrm{Cu}, \mathrm{Mn}, \mathrm{Ni}, \mathrm{Pb}, \mathrm{Zn}^{2+}$ ), both in high and low periods. From this, they observed that higher values occur in low period water, and lower values in the high water period due to the dilution effect. The authors concluded the lowland of Samborombón Bay would be retaining metals transported by the watercourses that drain to the bay. Recently, for the karst region of Lagoa Santa, MG, Brazil, Aragão et al. (2018) presented NBL values for some indicative elements of anthropic pollution: nitrate, nitrite, chloride, fluorine, phosphate, sulfate, and total solids dissolved. From the results, urban occupation anomalies were evidenced in some places of the study area. Therefore, the authors reported that the determination of NBL values proved to be an important tool in the management of groundwater resources, especially in aquifers more vulnerable to contamination, such as karst.

To date, there have been no other studies on this subject in the study area. The São Miguel River watershed from the Arcos Pains karst province is part of the São Francisco River watershed. Along with its karst aquifer, this system is the main source of water supply consumption for human, animal and irrigation in the region southeastern Brazil (Dias \& Velásques 2002, Menegasse et al. 2002, IGAM 2005, Haddad 2007, Haddad \& Magalhães Jr. 2010, SEE 2012, Pereira 2018).

The study aimed to establish NBL values for the groundwater of the karst region of the São Miguel River watershed and to understand the influence of seasonality. Knowing the NBL values of these waters becomes an indispensable measure to understand anomalies, especially those of human origin. Thus, NBL values can be used to establish regulating limits, which are of paramount importance to local administrators and environmental agencies (Edmunds et al. 2003).

\section{SITE DESCRIPTION}

The São Miguel River watershed $\left(520 \mathrm{~km}^{2}\right)$, located in the central-western region of the state of Minas Gerais, Brazil (Fig. 1), is characterized by a typical and well-developed karst, regarding both exo and endokarst levels (SEE 2012, SUPRAM 2013, Timo 2014). The springs of the São Miguel River are in the upstream portion of the basin, from where the river then flows northwards for approximately $53 \mathrm{~km}$, crossing five municipalities (Arcos, Pains, Iguatama, Formiga, and Córrego Fundo) before flowing into the São Francisco River, integrating the sub-watershed of the Upper São Francisco $\left(235.635 \mathrm{~km}^{2}\right)$.

According to the climatic classification proposed by Köppen and Geiger and updated by Alvares et al. (2013), the climate of the region is type Cwa, presenting warm and humid summers and dry winters. Menegasse et al. (2002) conducted a hydroclimatic characterization of the São Miguel River watershed using areas of influence of the Arcos, Iguatama and Olhos D’Água Farm stations, with data from 1975 through 1989, obtaining the mean rainfall value of $1.325 \mathrm{~mm}$. This value was very close to the mean rainfall value recorded for 2017 (1.379 mm). Regarding monthly rainfall, the driest month (August, $14 \mathrm{~mm}$ ) presented a difference in rainfall of $256 \mathrm{~mm}$ compared with the rainiest month (December, $270 \mathrm{~mm}$ ). Throughout the year, mean 
temperatures varied $6.6^{\circ} \mathrm{C}$, with $24^{\circ} \mathrm{C}$ found as the mean temperature of the warmest month of the year (January) and $17.4^{\circ} \mathrm{C}$ the mean value of the coldest month (June).

Geologically, the area is in the southwestern limit of the southern portion of the São Francisco Craton (Almeida 1977), which is characterized by the occurrence of Neoproterozoic limestones of the Sete Lagoas Formation (Bambuí Group), by Archean rocks of the Granite-Gneiss Complex (basement), and Cenozoic unconsolidated sediments (Félix \& Freitas Júnior 2000). Basement rocks outcrop only in the easternmost portion of the area with light gray, coarse-grained granitoids of incipient foliation, essentially composed of quartz, feldspars and biotite (Saadi 1991). Rocks from the Bambuí Group represented by the Sete Lagoas Formation (Dardenne 1978) lay discontinuously upon the basement. This formation is divided into two members (Ribeiro et al. 2003): Pedro Leopoldo, at the base, comprising light-colored calc-siltites, marls and pelites; and Lagoa Santa, at the top, characterized by medium to fine-grained dark limestones and dolomites. The latter member is the thickest and is distributed over a larger area across the São Miguel River watershed (Fig. 2).

The groundwater of the Upper São Francisco region is compartmented into four aquifer systems (Mourão et al. 2001): granular (alluvial, sandstone, and colluvial-eluvial); karst; karst-fissure; and fissure (metapelites, schists, quartzites, itabirites, and metamorphic rocks). Regarding the karst aquifers, values of transmissivity $(T)$ and, consequently, conductivity $(K)$ and hydraulic permeability $(k)$ may vary according to the vertical position of limestones, which, in most cases, are higher in zones which present more altered limestones, near the surface (epikarst), exponentially decreasing as depth increases. Similarly, in the karst aquifers of the Sete Lagoas Formation in the municipality of Sete Lagoas (MG), Galvão et al. (2015) identified increase between four and six orders of magnitude in hydraulic conductivity values.

Pereira (2018) reported that pastures represent the highest percentage of land use in the basin $(61 \%)$, constituted by agricultural and livestock areas, while mining and urban occupation areas compound the total of 3.5\% (Fig. 3).

\section{MATERIALS AND METHODS}

Groundwater samples were seasonally surveyed in the study, and the chemical signature of certain elements were statistically analyzed to understand the influence of seasonality, geology, and use and occupation of the targeted watershed.

Four sampling campaigns were conducted (two during the dry season and two during the rainy season) for the hydrochemical monitoring of the watershed. These campaigns took place in four different types of sampling stations: dug wells (6) (excavated in soil, 3 to $12 \mathrm{~m}$ ), tubular
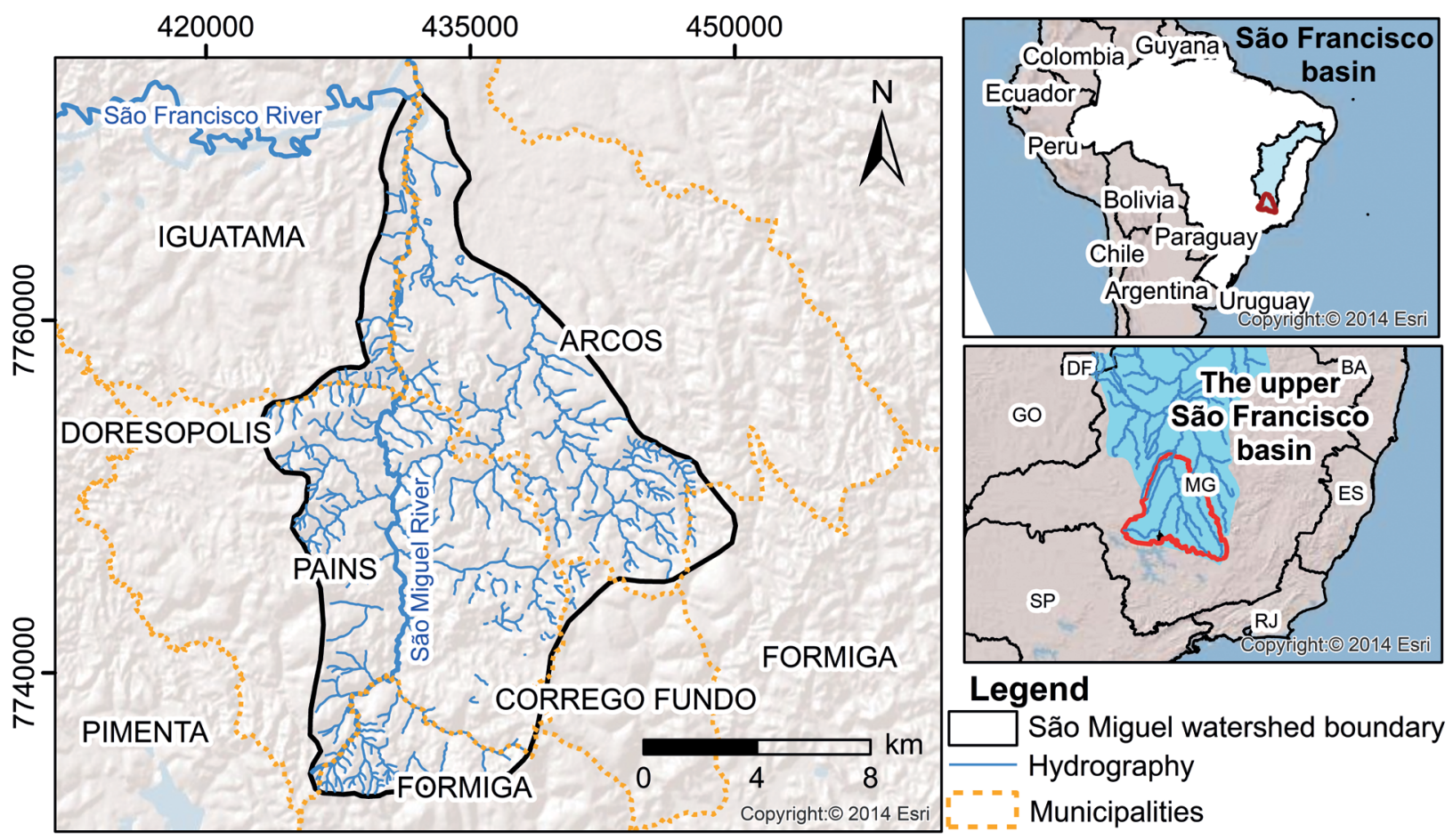

Figure 1. Location map of the São Miguel river watershed and surrounding municipalities. 
wells (16) (depths varying from 8 to $150 \mathrm{~m}$ ), springs/sinkholes (3) (with small stretches of exposed river), and caves (9) (Vaca Queimada, Moranga, Éden, Loca Feia, Mastodonte, and Narigudo caves presenting underground river; Loca D'água cave presenting a spring, and Carneiro and Lagoa do Retiro caves presenting water flows that disappear inside the caves where the route of these waters are unknown) (Fig. 2). The total of 153 samples were collected, of which 78 were taken during the dry season and 75 during the rainy season.

The land use map adapted by Pereira (2018) (Fig. 3) was made using images with spatial resolution of $30 \mathrm{~m}$, captured in 2014 by the operational land imager sensor (OLI) installed onboard the Landsat- 8 satellite, made available by the US Geological Survey (USGS). These images were analyzed using the software ESRI ArcGIS 10.3.

Water samples were filtered, acidified with ultrapure nitric acid, and stored in a fridge at $4^{\circ} \mathrm{C}$. The concentrations of the chemical elements $\mathrm{Ca}^{2+}, \mathrm{K}^{+}, \mathrm{Mg}^{2+}, \mathrm{Na}^{+}, \mathrm{Zn}^{2+}$, and $\mathrm{As}^{3+}$ were analyzed via inductively coupled plasma atomic emission spectrometry (ICP-OES Agilent 725) and inductively coupled plasma mass spectrometry (ICP-MS Agilent 7700x) in the Geochemistry Laboratory of the Department of Geology at the Universidade Federal de Ouro Preto. Nitrates, sulfates, phosphates and chlorides were measured using a DR890 $\mathrm{HACH}$ model field colorimeter, and its respective reagents: NitraVer ${ }^{\circledR}$ (nitrate reagent), Phos $\mathrm{Ver}^{\circledR} 3$ (phosphate reagent), SulfaVer ${ }^{\circledR}$ (sulfate reagent) and Chlorine; all reagents were from $\mathrm{HACH}^{\circledR}$. Finally, alkalinity was determined through the titration method (Greenberg et al. 1995).

Only results that presented ionic balance difference (IBD) values ranging $10 \%$ were used to calculate this parameter (Custodio \& Llamas 2001, Feitosa et al. 2008). Water geochemical types were determined by using the Piper diagram (Piper 1944).

NBL, meaning the accumulated frequency of the concentrations of samples collected according to the methods proposed by ISPRA (2009) and APAT-ISS (2006), were considered to calculate NBL values. These values for groundwater

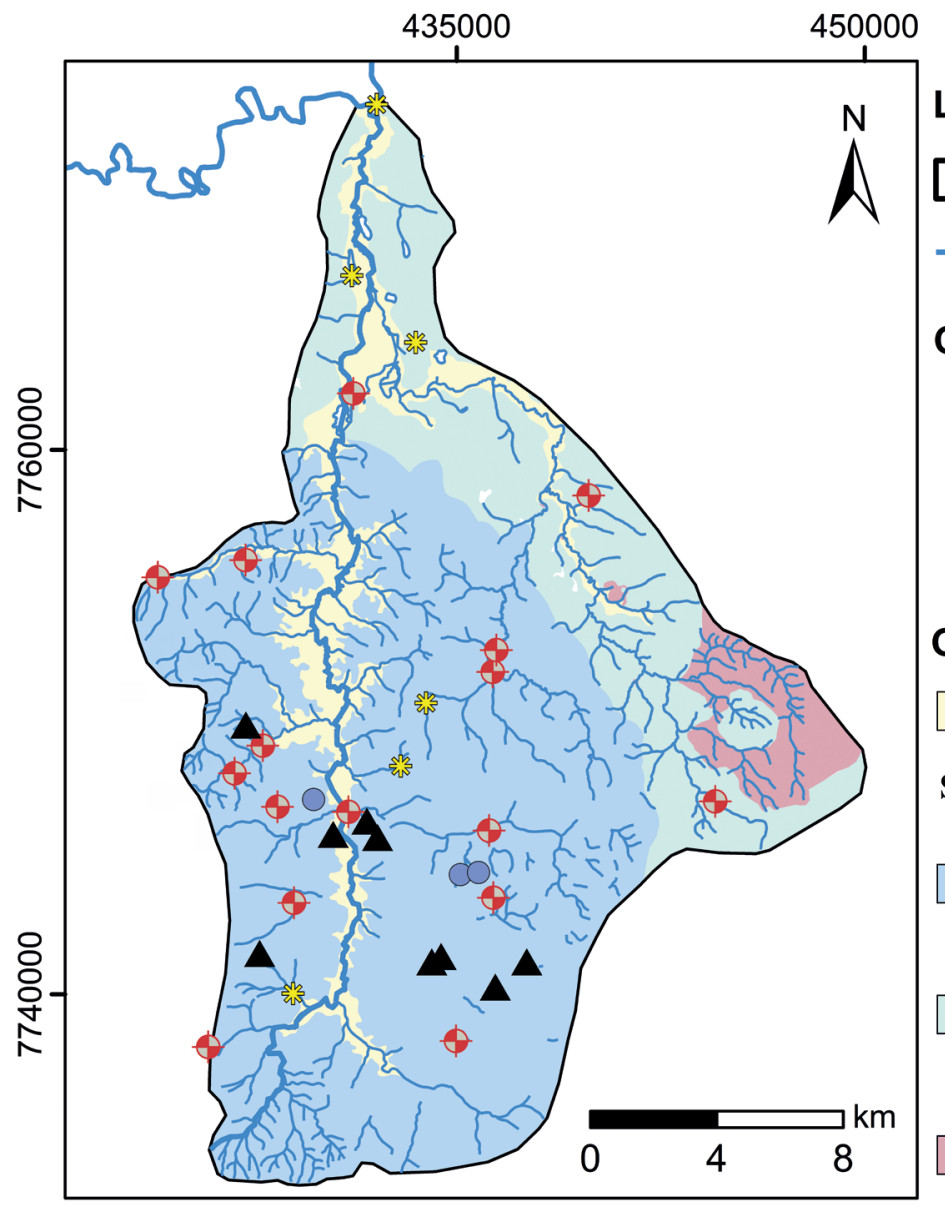

\section{Legend}

$\square$ São Miguel watershed

- Hydrography

\section{Groundwater sampling points}

粠 Dug well

$\Delta$ Cave

- Tubular well

Sink and sinkhole

\section{Geological context}

Cenozoic unconsolidated sediments

\section{Sete Lagoas Formation}

Lagoa Santa Member: calcarenites on dolomitic calcarenites and calcipelites

Pedro Leopoldo Member: calcipelites, calcissiltites and calcilutites

\section{Basement}

Granitic to granodioritic rocks

Figure 2. Sampling points and geological map of the São Miguel watershed (adapted from Ribeiro et al. 2008, CPRM 2012). 
are defined as the $90^{\text {th }}$ and $95^{\text {th }}$ percentiles derived from the probability distribution per sampling period (dry and rainy season). Statistical treatment of data and box plots were elaborated using the Office platform and the software Minitab 16. Hydrochemical data obtained were plotted as isovalue maps using the software ArcGIS 10.3, applying the following system tools (extensions): Spatial Analyst, Spatial Tools and Inverse Distance Weighted (IDW).

\section{RESULTS AND DISCUSSION}

Some anomalies, which will be described ahead, are possibly related to watershed use and occupation patterns; this condition can be better understood through an analysis of Figure 3. This figure shows access roads and two large urban centers, the municipality of Arcos to the east, and Pains in the central portion of the watershed. In addition, there is a large number of mining sites over the area, the majority of which is located within the Lagoa Santa Member (Fig. 2). Agricultural activities (bean, corn and sugar cane crops, eucalyptus plantations, and pastures), livestock activities and remnants of native vegetation are distributed across the entire watershed.

Groundwater in the São Miguel River watershed can be predominantly classified as calcium bicarbonate type (Fig. 4), reflecting the essentially carbonate composition of the geologic framework (Fig. 2).

NBL values and TV for $\mathrm{Ca}^{2+}, \mathrm{K}^{+}, \mathrm{Mg}^{2+}, \mathrm{Na}^{+}$and anions analyzed are shown in Table 1 and Figure 5. The maps shown in Figure 6 present the geographic distribution of these cations. While the highest, above NBL 90\% values for calcium (112.99 in dry and $120.86 \mathrm{mg} / \mathrm{L}$ in rainy season) and magnesium (14.43 in dry and $14.24 \mathrm{mg} / \mathrm{L}$ in rainy season) occurred in the central region of the watershed,

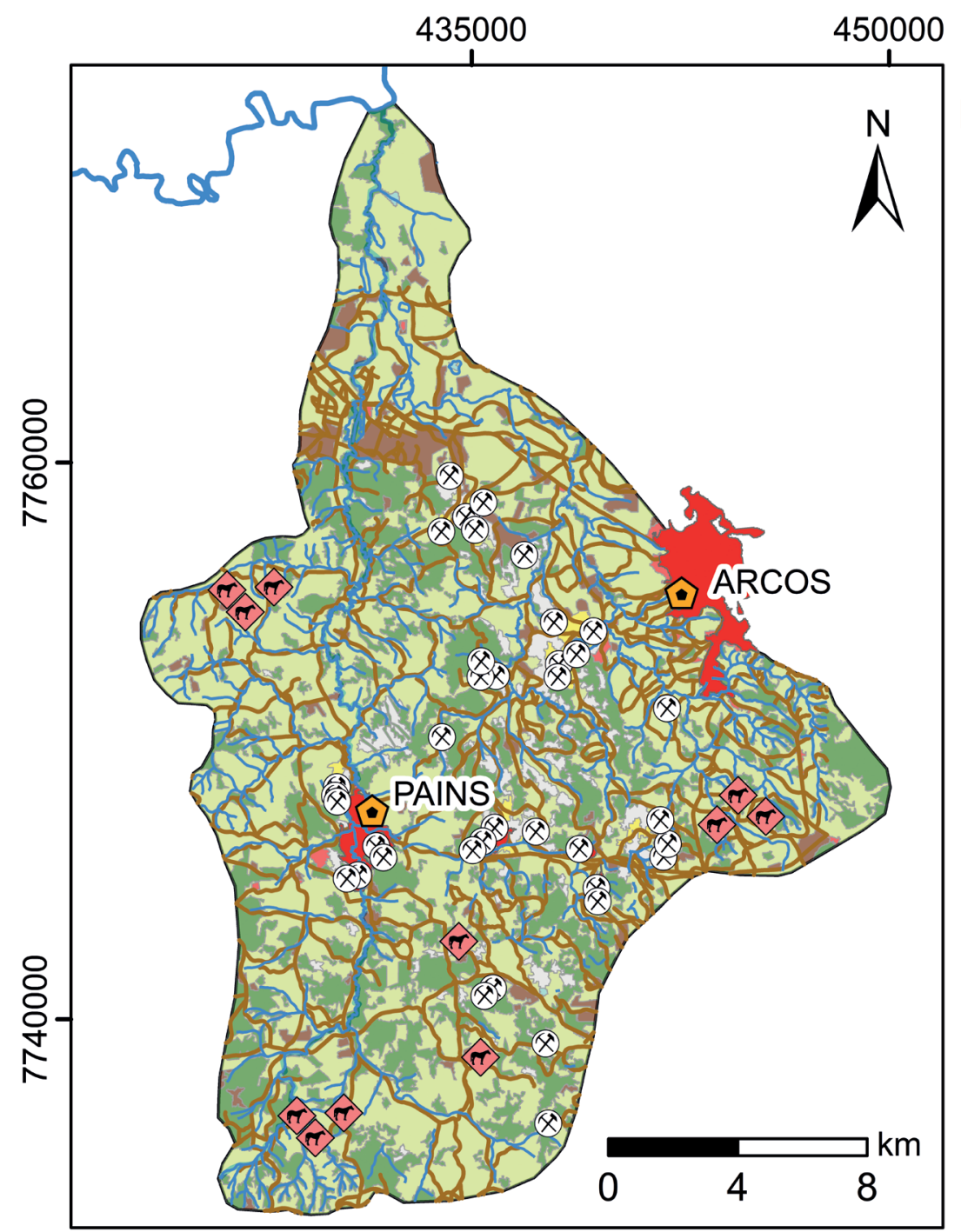

\section{Legend}

$\square$ São Miguel watershed

_ Hydrography

Road

(1) Livestock

(メ) Mining

- Municipal centers

\section{Land use and ocupation}

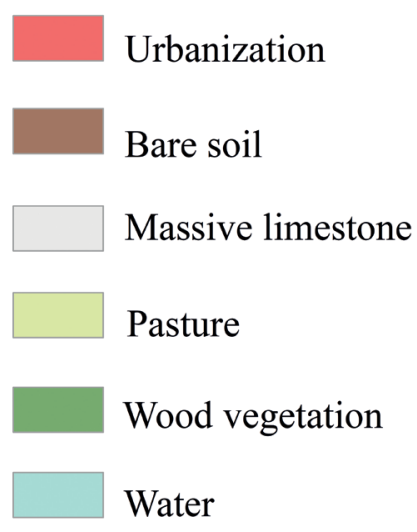

Figure 3. São Miguel watershed land use map, adapted by Pereira (2018). 


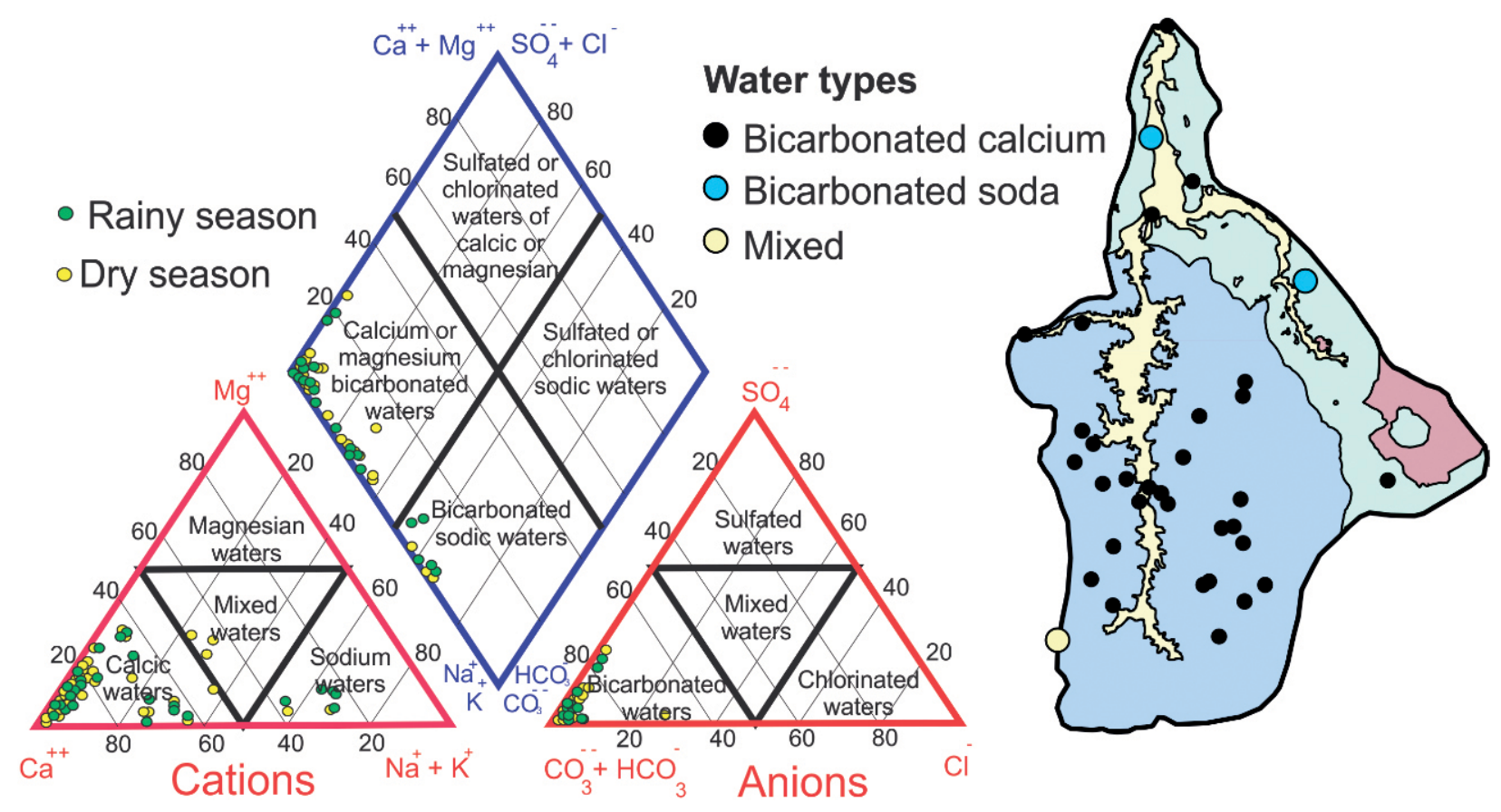

Figure 4. Piper diagram hydrochemical classification of the São Miguel watershed groundwater.

Table 1. Natural Background Level (NBL) and threshold values (TVs) of $\mathrm{Ca}^{2+}, \mathrm{K}^{+}, \mathrm{Mg}^{2+}, \mathrm{Na}^{+}$and anions for of the São Miguel watershed groundwater.

\begin{tabular}{|c|c|c|c|c|c|c|c|c|c|c|c|c|c|c|c|c|c|c|}
\hline \multirow[b]{3}{*}{ Season } & \multicolumn{8}{|c|}{ Cations } & \multicolumn{10}{|c|}{ Anions } \\
\hline & \multicolumn{2}{|c|}{$\mathrm{Ca}^{2+}(\mathrm{mg} / \mathrm{L})$} & \multicolumn{2}{|c|}{$\mathrm{Mg}^{2+}(\mathrm{mg} / \mathrm{L})$} & \multicolumn{2}{|c|}{$\mathrm{Na}^{+}(\mathrm{mg} / \mathrm{L})$} & \multicolumn{2}{|c|}{$\mathbf{K}^{+}(\mathbf{m g} / \mathrm{L})$} & \multicolumn{2}{|c|}{$\mathrm{HCO}_{3}^{-}(\mathrm{mg} / \mathrm{L})$} & \multicolumn{2}{|c|}{$\mathrm{SO}_{4}{ }^{2-}(\mathrm{mg} / \mathrm{L})$} & \multicolumn{2}{|c|}{$\mathrm{Cl}^{-}(\mathrm{mg} / \mathrm{L})$} & \multicolumn{2}{|c|}{$\mathrm{NO}_{3}^{-}(\mathrm{mg} / \mathrm{L})$} & \multicolumn{2}{|c|}{$\mathrm{PO}_{4}{ }^{3-}(\mathrm{mg} / \mathrm{L})$} \\
\hline & Dry & Rainy & Dry & Rainy & Dry & Rainy & Dry & Rainy & Dry & Rainy & Dry & Rainy & Dry & Rainy & Dry & Rainy & Dry & Rainy \\
\hline $\mathrm{REF}^{*}$ & \multicolumn{2}{|c|}{ - } & \multicolumn{2}{|c|}{ - } & \multicolumn{2}{|c|}{ - } & \multicolumn{2}{|r|}{ - } & \multicolumn{2}{|r|}{ - } & \multicolumn{2}{|c|}{250} & & & \multicolumn{2}{|c|}{10} & \multicolumn{2}{|c|}{100} \\
\hline NBL (90\%) & 112.99 & 120.86 & 14.43 & 14.24 & 7.53 & 4.74 & 1.72 & 2.43 & 430.07 & 435.64 & 17.5 & 24.05 & 0.3 & 0.63 & 9.25 & 13.67 & 0.82 & 0.68 \\
\hline NBL (95\%) & 124.31 & 132.47 & 16.45 & 16.17 & 9.05 & 5.51 & 1.96 & 2.79 & 472.23 & 473.46 & 21.4 & 29.52 & 0.35 & 0.74 & 10.35 & 15.79 & 0.96 & 0.77 \\
\hline $\begin{array}{l}\text { TV (median + } \\
\left.2^{*} \mathrm{SD}\right)\end{array}$ & 138.96 & 149.83 & 17.51 & 17.84 & 9.35 & 5.45 & 2.07 & 2.97 & 532.98 & 533.89 & 21.6 & 30.14 & 0.35 & 0.61 & 11.00 & 16.08 & 0.97 & 0.83 \\
\hline $\begin{array}{l}\text { TV (average + } \\
2^{*} \mathrm{SD} \text { ) }\end{array}$ & 135.37 & 143.81 & 18.41 & 18.05 & 10.5 & 6.26 & 2.2 & 3.15 & 513.46 & 510.43 & 25.3 & 34.87 & 0.4 & 0.85 & 11.44 & 17.87 & 1.08 & 0.86 \\
\hline $\begin{array}{l}\text { No. of } \\
\text { samples }\end{array}$ & 78 & 75 & 78 & 75 & 78 & 75 & 78 & 75 & 78 & 75 & 78 & 75 & 78 & 75 & 78 & 75 & 78 & 75 \\
\hline Minimum & 1.40 & 1.44 & 0.12 & 0.17 & 0.22 & 0.12 & 0.17 & 0.17 & 8.31 & 27.71 & 0 & 0 & 0 & 0 & 0 & 0.15 & 0 & 0.08 \\
\hline Maximum & 130.10 & 145.28 & 24.01 & 23.40 & 35.3 & 8.81 & 3.73 & 5.23 & 477.96 & 479.81 & 80 & 80 & 0.83 & 2.2 & 16.5 & 30 & 2.24 & 1.81 \\
\hline Average & 73.08 & 79.93 & 7.33 & 7.45 & 2.16 & 2.03 & 0.86 & 1.15 & 281.31 & 302.23 & 3.64 & 4.73 & 0.12 & 0.26 & 5.33 & 6.19 & 0.36 & 0.34 \\
\hline Median & 76.67 & 85.95 & 6.44 & 7.24 & 0.97 & 1.21 & 0.73 & 0.97 & 300.84 & 325.69 & 0 & 0 & 0.07 & 0.2 & 4.9 & 4.4 & 0.25 & 0.32 \\
\hline SD & 31.14 & 31.94 & 5.53 & 5.3 & 4.19 & 2.11 & 0.67 & 0.99 & 116.07 & 104.10 & 10.8 & 15.07 & 0.14 & 0.29 & 3.05 & 5.84 & 0.36 & 0.25 \\
\hline Q1 & 60.31 & 74.60 & 2.58 & 2.78 & 0.56 & 0.76 & 0.44 & 0.50 & 222.19 & 271.42 & 0 & 0 & 0.03 & 0.1 & 3.37 & 2.7 & 0.18 & 0.22 \\
\hline Q3 & 92.96 & 99.28 & 10.17 & 10.54 & 2.05 & 1.85 & 1 & 1.41 & 374.19 & 370.04 & 1 & 2 & 0.16 & 0.3 & 6.45 & 8 & 0.38 & 0.4 \\
\hline
\end{tabular}

REF*: reference according to Portaria n 2.914, de 12 de dezembro de 2011; SD: standard deviation. 
anomalous concentrations of potassium $\left(\mathrm{K}^{+}\right)(1.72$ in dry and $2.43 \mathrm{mg} / \mathrm{L}$ in rainy season) occurred mainly in the area where the granitic basement outcrops, to the east. In turn, anomalous concentrations of sodium $\left(\mathrm{Na}^{+}\right)$(7.53 in dry and $4.74 \mathrm{mg} / \mathrm{L}$ in rainy season) occurred in the northern area of the watershed, close to the river mouth (Fig. 6).

These behaviors seem to reflect geogenic influence (Fig. 2) and anthropogenic contributions, whether due to mining-related activities or influence from the use of chemical fertilizers in agriculture, or even domestic effluent discharge (Fig. 3).

Dias-Oliveira et al. (2017) reported that the highest concentrations of calcium and magnesium for the groundwater of the São Miguel River watershed were found near mining activities. This corroborates Fritzsons et al. (2009), who, in a study conducted in the karst region of the state of Paraná, southern Brazil, reported that local mining activities altered waters, since dolomites, when extracted from quarries release calcium and magnesium carbonate in the environment, due to an increase in contact surface for dissolution processes. Still according to these authors, surface water quality is influenced by limestone mining activities and the implications of this finding on water bodies should be better studied, especially regarding the biota of the aquatic ecosystem.

Tedd et al. (2017) calculated NBL 95\% values for the main cations of waters in Ireland and from these values they related the type of aquifer (unconfined and confined) and the main lithological groups (Tab. 2). The values obtained for NBL $95 \%$ for $\mathrm{Ca}^{2+}, \mathrm{Mg}^{2+}, \mathrm{Na}^{+}$and $\mathrm{K}^{+}$of the studied waters (Tab. 1) show the occurrence of unconfined aquifers. Regarding lithological groups, values of $\mathrm{Ca}^{2+}$ and $\mathrm{Mg}^{2+}$
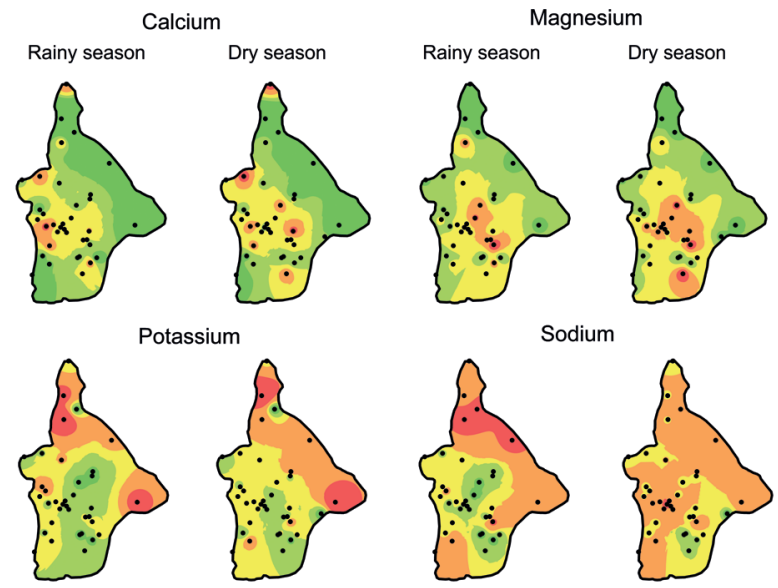

Sodium
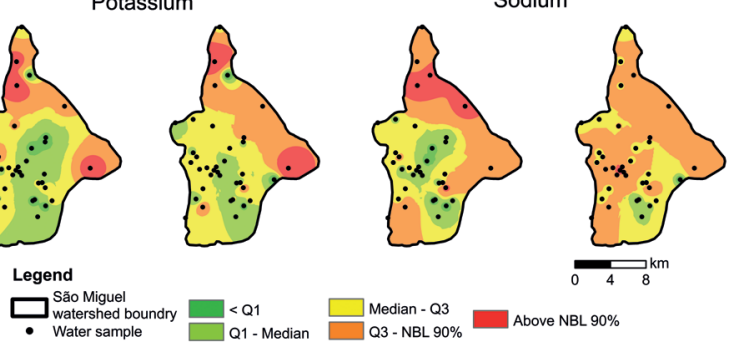

Figure 6. Hydrochemical maps with distinction of Natural Background Level (NBL) $90 \%$ for calcium, magnesium, potassium and sodium.

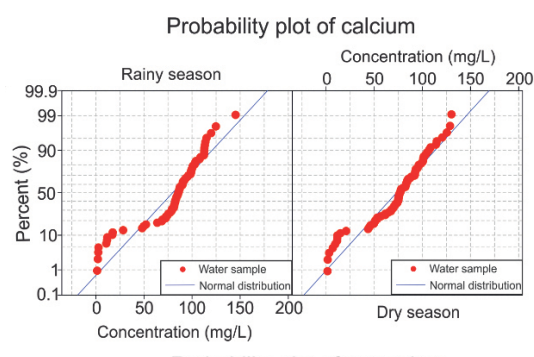

Probability plot of potassium

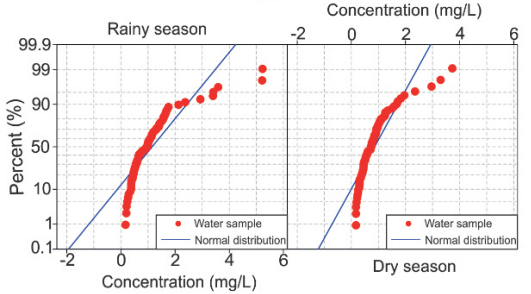

Probability plot of bicarbonate
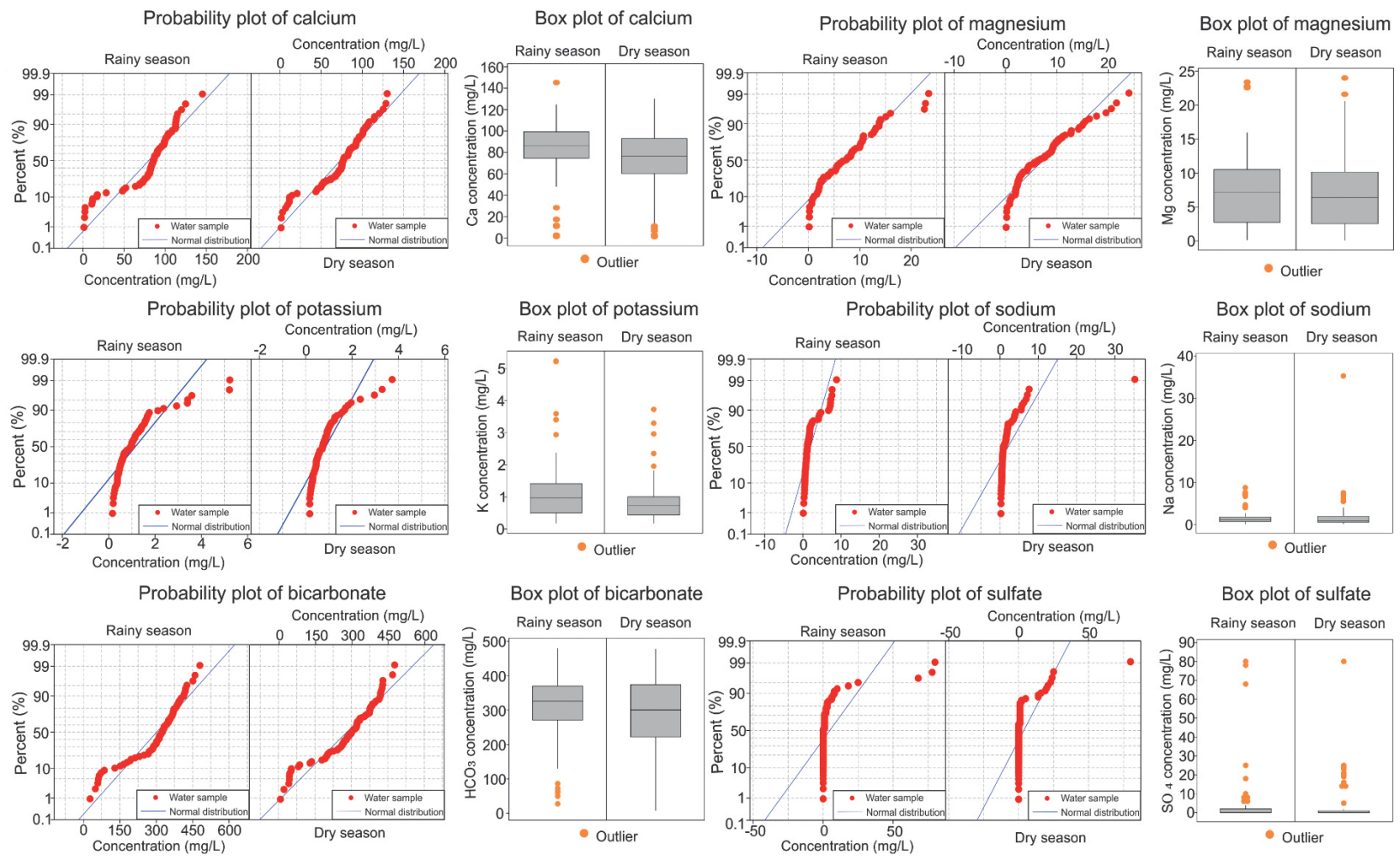

Figure 5. Seasonal probability plot and box plot for calcium, magnesium, potassium, sodium, bicarbonate and sulfate. 
indicate the occurrence of pure limestones, while potassium also indicates the occurrence of pure limestones and other sedimentary rocks, and finally, sodium points out the occurrence of gravel, sand and igneous rocks.

Additionally, in the surroundings of the urban area of the municipality of Pains, Pires (2017) and Meyer (2018) conducted chemical analyses of 23 samples of carbonate rocks from the Lagoa Santa Member and obtained mean concentrations of $\mathrm{Ca}^{2+}(284.51 \mathrm{~g} / \mathrm{kg}), \mathrm{Na}^{+}(0.26 \mathrm{~g} / \mathrm{kg}), \mathrm{K}^{+}$ $(3.14 \mathrm{~g} / \mathrm{kg})$ and $\mathrm{Mg}^{2+}(65.74 \mathrm{~g} / \mathrm{kg})$.

Regarding anions $\left(\mathrm{HCO}_{3}^{-}, \mathrm{SO}_{4}^{2-}, \mathrm{NO}_{3}^{-}, \mathrm{Cl}^{-}\right.$, and $\left.\mathrm{PO}_{4}^{3-}\right)$ (Tab. 1, Figs. 7, 8, 9), bicarbonate presented distinctly higher concentrations compared with the others, with seasonal variation of the NBL $90 \%$ value (430.07 and $435.64 \mathrm{mg} / \mathrm{L}$ ).

The highest values of bicarbonate (median — above NBL 90\%) (above median $=300.84 \mathrm{mg} / \mathrm{L}$ in dry and above median $=325.69 \mathrm{mg} / \mathrm{L}$ in rainy season) occurred in the central western region of the watershed, where limestones of the Lagoa Santa Member outcrop. It is important to highlight these values are closely related to the natural dissolution of soils and rocks (Dimitrijevic 1995), proving these limestones are more karstifiable than the Pedro Leopoldo Member, because they are purer (Galvão et al. 2016). For sulfate, the high concentrations (above Q3 = $1 \mathrm{mg} / \mathrm{L}$ in dry and above Q3 = $2 \mathrm{mg} / \mathrm{L}$ in rainy season) dispersed over the watershed suggest geogenic influence due to the water-aquifer interaction related to the direct exchange of anions between groundwater and the clay fraction of the aquifer, which may also originate from rock dissolutions or/and even rainwater (Silva 1983, Flues et al. 2003). Meyer (2018) identified for the studied area the occurrence of carbonates with pyrite and galena, which could be the responsible for releasing sulfur into the water.

The anomalies observed (values above NBL 90\%) for nitrate $(9.25 \mathrm{mg} / \mathrm{L}$ in dry and $13.67 \mathrm{mg} / \mathrm{L}$ in rainy season), phosphate $(0.82 \mathrm{mg} / \mathrm{L}$ in dry and $0.68 \mathrm{mg} / \mathrm{L}$ in rainy season $)$ and chloride $(0.3 \mathrm{mg} / \mathrm{L}$ in dry and $0.63 \mathrm{mg} / \mathrm{L}$ in rainy season) occurred in the eastern and western regions of the watershed. They are directly connected to human activities, originated from precarious sewage collection and treatment systems, with excessive organic matter found in the environment, or even due to intensive use of nitrogen-based fertilizers, since these areas present high agricultural and livestock productivity (Fig. 3).

During the rainy season, nitrate presented concentrations higher than the limit of $10 \mathrm{mg} / \mathrm{L}$, established by current legislation: Companhia Ambiental do Estado de Sáo Paulo (CETESB 2014), Conselho Nacional do Meio Ambiente (Conama) No. 396 (Brasil 2008), Portaria do Ministério da Saúde no 2.914 (Brasil 2011), drinking water standards of United States Environmental Protection Agency (USEPA 2017), and Canadian Council of Resource and Environmental Ministers (CCREM 1987). Zublena et al. (2001) reported that nitrate is considered a powerful carcinogenic agent and high concentrations in supply waters may lead to countless public health problems (Lalehzari et al. 2013), such as methemoglobinemia, also known as blue baby syndrome, which consists of low blood oxygenation and affects newborns.

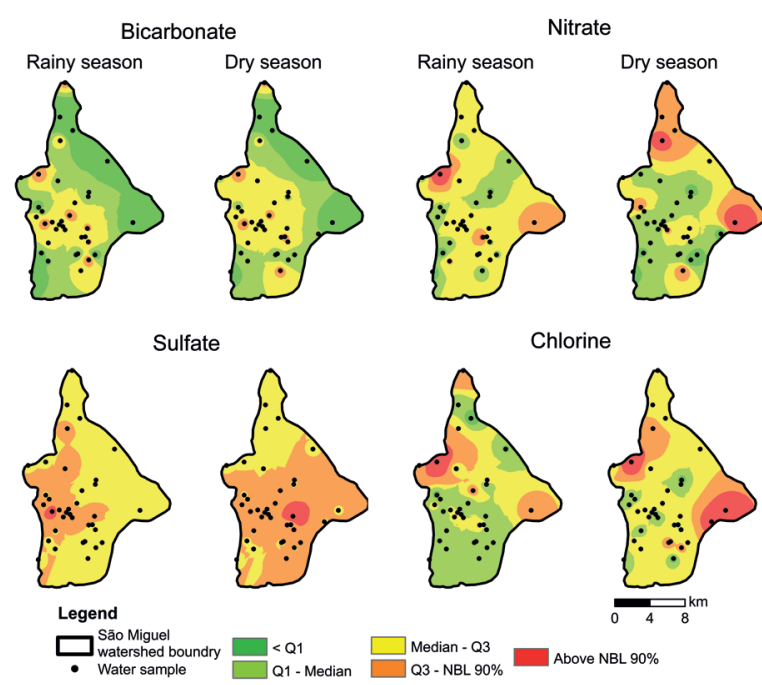

Figure 7. Hydrochemical maps with distinction of Natural Background Level (NBL) 90\% for bicarbonate, nitrate, sulfate and chlorine.

Table 2. Natural Background Level (NBL) $95 \%$ values in $\mathrm{mg} / \mathrm{L}$ for $\mathrm{Ca}^{2+}, \mathrm{Mg}^{2+}, \mathrm{Na}^{+}$and $\mathrm{K}^{+}$elements of Irish waters and their respective description of aquifer and rock type (Tedd et al. 2017).

\begin{tabular}{|c|c|c|c|c|c|c|c|c|}
\hline Element & $\begin{array}{l}\text { Unconfined } \\
\text { MPs }\end{array}$ & $\begin{array}{l}\text { Confined } \\
\text { MPs }\end{array}$ & $\begin{array}{l}\text { Sand and } \\
\text { gravel }\end{array}$ & $\begin{array}{l}\text { Impure } \\
\text { limestones }\end{array}$ & $\begin{array}{c}\text { Pure } \\
\text { limestones }\end{array}$ & $\begin{array}{l}\text { Non calcareous } \\
\text { sedimentary }\end{array}$ & Igneous & Metamorphic \\
\hline $\mathrm{Ca}^{2+}$ & 112.93 & 109.10 & 111.24 & 112.85 & 117.30 & 63.63 & 8.17 & 114.16 \\
\hline $\mathrm{Mg}^{2+}$ & 16.53 & 42.46 & 7.83 & 11.32 & 17.55 & 11.32 & 1.68 & 13.67 \\
\hline $\mathrm{K}^{+}$ & 2.10 & 5.86 & 1.10 & 1.80 & 2.22 & 2.12 & 0.45 & 1.80 \\
\hline $\mathrm{Na}^{+}$ & 13.07 & 105.44 & 10.21 & 10.55 & 13.84 & 12.51 & 6.95 & 12.17 \\
\hline
\end{tabular}

MP: monitoring points. 
$\mathrm{NBL}$ and TV for $\mathrm{As}^{3+}, \mathrm{Ba}^{2+}$ and $\mathrm{Zn}^{2+}$ are shown in Table 3 and Figure 8, while the maps of Figure 9 present the geographic distribution of these elements.

The highest values of NBL $90 \%$ for $\mathrm{As}^{3+}(2.48 \mu \mathrm{g} / \mathrm{L}$ in dry and $3.29 \mu \mathrm{g} / \mathrm{L}$ in rainy season) and $\mathrm{Zn}^{2+}(24.67 \mu \mathrm{g} / \mathrm{L}$ in dry and $37.70 \mu \mathrm{g} / \mathrm{L}$ in rainy season) occurred during the rainy season. On the other hand, the highest values for $\mathrm{Ba}^{2+}$ occurred during the dry season. The same well (150-m deep tubular well located in the central portion of the watershed - Amargoso Farm) presented anomalous concentrations of $\mathrm{As}^{3+}$ during the rainy $(12.70 \mathrm{ug} / \mathrm{L})$ and dry $(10.83 \mathrm{ug} / \mathrm{L})$ seasons (Fig. 9). It is important to highlight that values obtained with NBL $90 \%$ above $0.02 \mu \mathrm{g} / \mathrm{L}$ for arsenic are considered as "risk areas" by Connecticut, United States. The anomaly observed may be related to either limestones and dolomites of the Sete Lagoas Formation or human contributions derived from the use of fertilizers. According to Tedd et al. (2017), values of NBL $95 \%$ of arsenic $(2 \mu \mathrm{g} / \mathrm{L})$ suggest the occurrence of unconfined aquifers and may indicate the presence of impure limestones $(3 \mu \mathrm{g} / \mathrm{L})$. On the other hand, Villanueva et al. (2014) conducted a hydrochemical characterization of the Salitre Karst Aquifer in Irecê (BA) and observed that the origin of arsenic for the region was related to the inadequate use of fertilizers in crops of the area.

The highest concentrations of barium $(94.44 \mu \mathrm{g} / \mathrm{L}$ in dry and $84.35 \mu \mathrm{g} / \mathrm{L}$ in rainy season) and zinc $(24.67 \mu \mathrm{g} / \mathrm{L}$ in dry and $37.70 \mu \mathrm{g} / \mathrm{L}$ in rainy season), which were above NBL $90 \%$, were observed in the eastern region of the watershed, thus possibly reflecting the geogenic influence of the granite/gneiss basement. This result corroborates Tedd et al. (2017), who reported values of NBL $95 \%$ of $114.10 \mu \mathrm{g} / \mathrm{L}$ for $\mathrm{Ba}^{2+}$, and between 28.48 and $44.47 \mu \mathrm{g} / \mathrm{L}$ for $\mathrm{Zn}^{2+}$. For
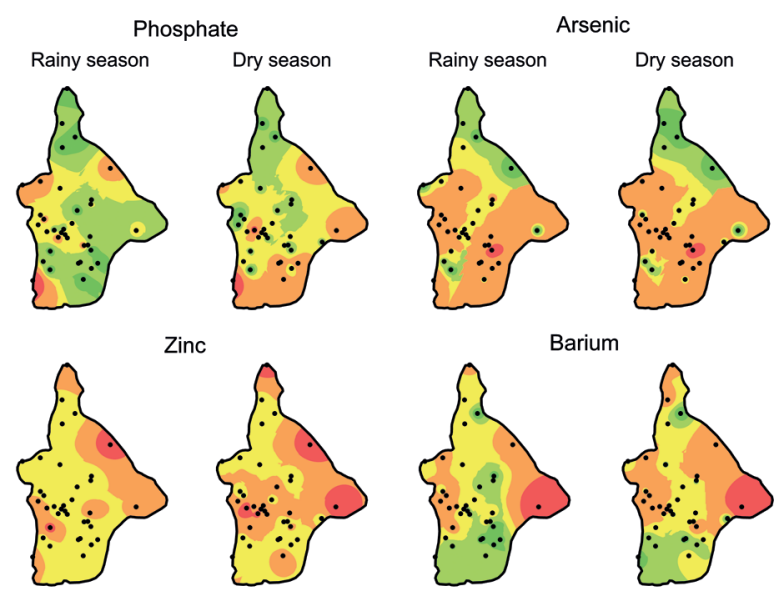

Barium
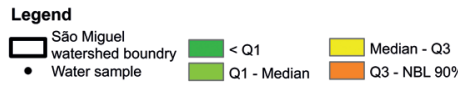

Q3 $90 \%$

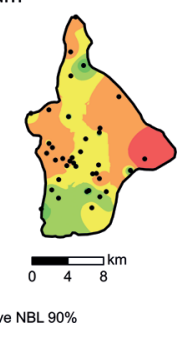

Figure 9. Hydrochemical maps with distinction of Natural Background Level (NBL) 90\% for phosphate, arsenic, zinc and barium.

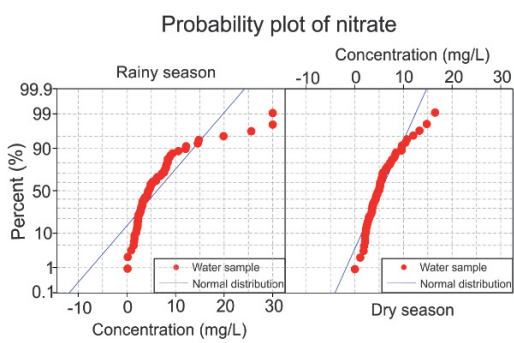

Probability plot of phosphate

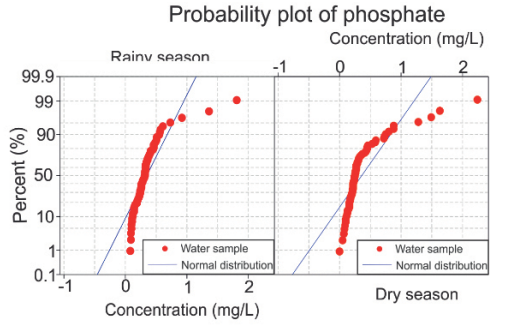

Probability plot of barium

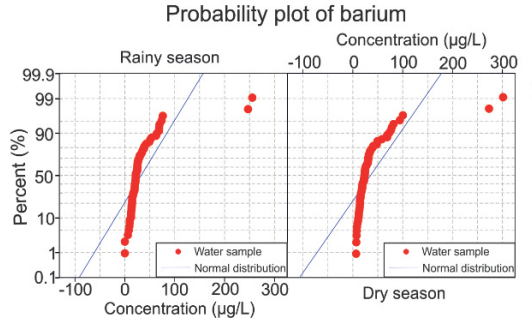

Figure 8. Seasonal probability plot and box plot for nitrate,

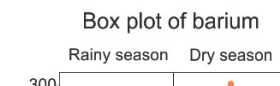

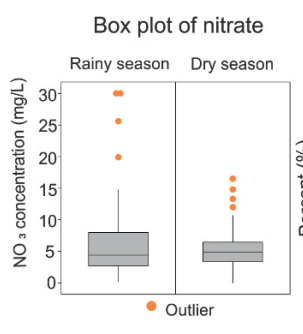
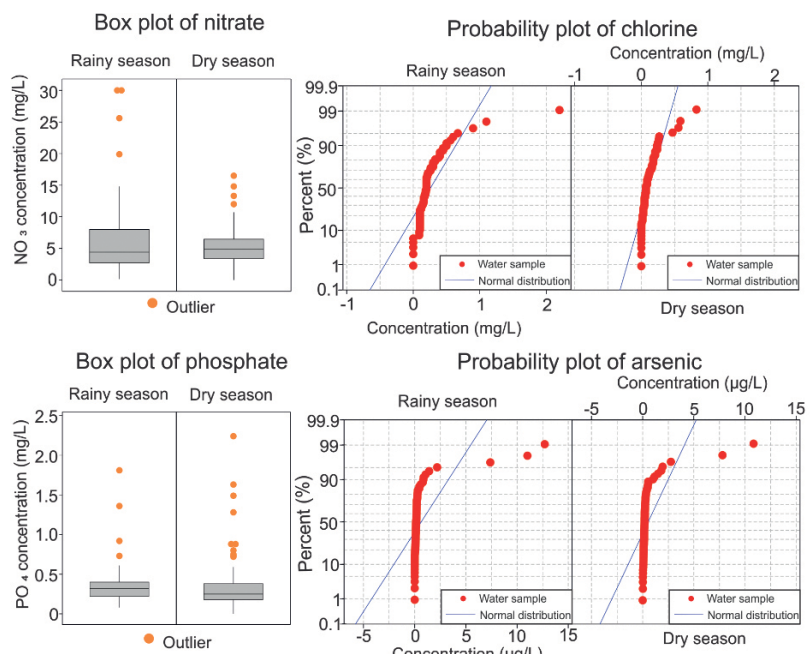

Probability plot of arsenic
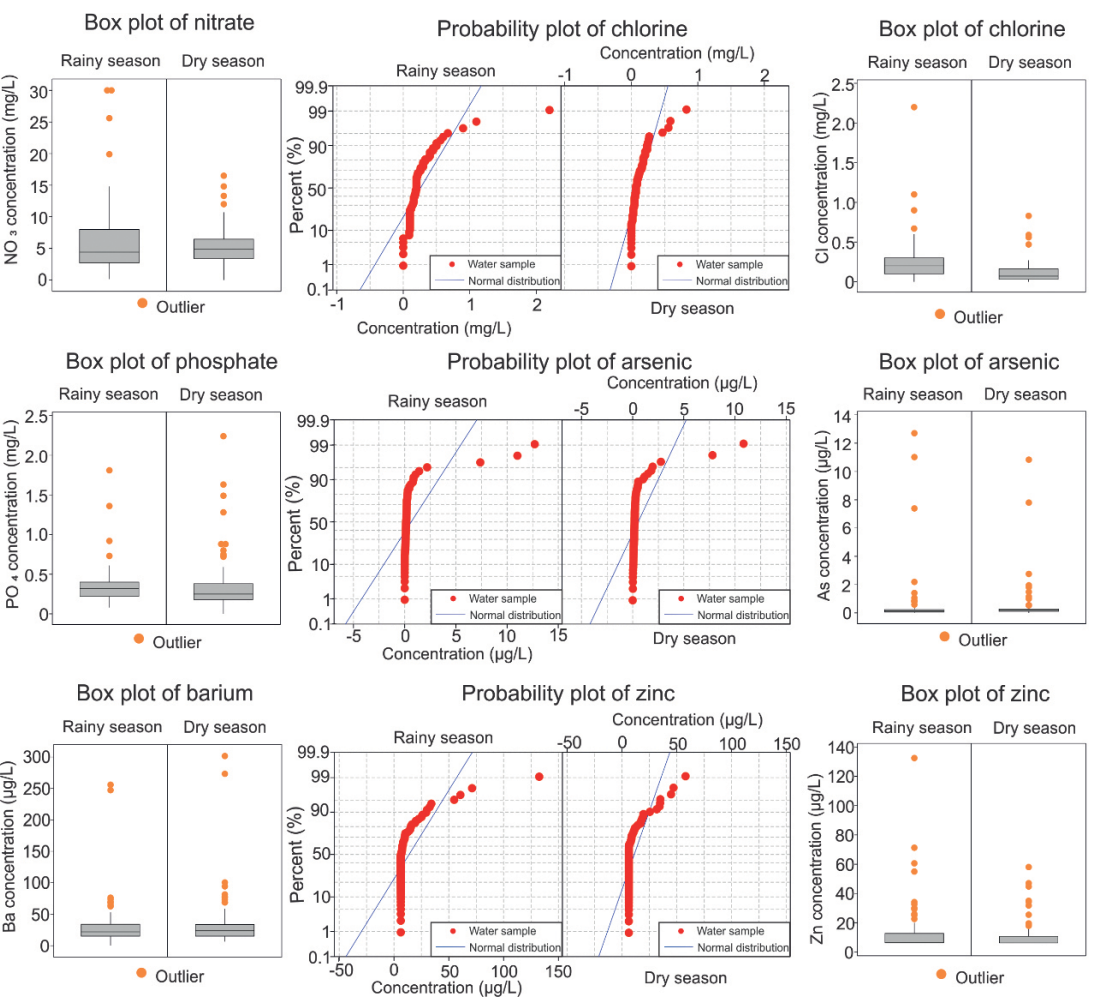
these authors, these results may indicate the occurrence of metamorphic rocks.

Therefore, the data collected showed the origin (geogenic or anthropogenic) of each anomaly reported and allowed defining their main source of contribution. Moreover, the data improved the understanding of the hydrochemical behavior of these elements based on values of NBL $90 \%$ in face of the seasonality of the region (Tab. 4).

\section{CONCLUSION}

The study allowed to determine background values (NBL and TV) and delimitate areas with the highest possibility of anthropogenic and geogenic influences on the geochemical anomalies observed. The use of hydrochemical maps designed according to the spatial distribution of NBL values was shown to be a valuable tool. In addition, the results allowed to elucidate element origin and behavior, and to understand the hydrochemical behavior and influence of seasonality for the elements $\mathrm{As}^{3+}, \mathrm{Ba}^{2+}, \mathrm{Ca}^{2+}, \mathrm{K}^{+}, \mathrm{Mg}^{2+}, \mathrm{Na}^{+}$and $\mathrm{Zn}^{2+}$ in the groundwater of the Sáo Miguel River watershed.

Concentrations and values of NBL $90 \%$ of nitrate and arsenic surpassed legally established limits, respectively $10 \mathrm{mg} / \mathrm{L}$ and $10 \mu \mathrm{g} / \mathrm{L}$. The origin of these anomalies observed for nitrate was anthropogenic, especially from agricultural and livestock activities. In turn, the origin of arsenic anomalies could be either natural or anthropogenic, demanding more detailed studies in order to understand this condition.

Monitoring the quality of water resources and proposing NBL values for a watershed are essential tools to understand lithological and human influence in the studied groundwater, helping to identify the most vulnerable areas and elucidate the origin of anomalies, providing subsides for the management of these areas.

The term natural background level may give only the idea of geogenic origin. However, the concept refers to concentration values that also depend on the level and type of land use, which also may indicate potential anthropogenic influences. In the case of karst aquifers, they can be very well-interconnected and heterogeneous, making them extremely difficult to verify sources of anomalies (anthropogenic or geogenic) because waters from different origins can be mixed within the aquifer, even seasonally. Thus, studies developed in these areas can be more limited compared to non-karst aquifers. To minimize those limitations, it is important further and more detailed studies about application and concept of NBL in karst regions, associating with other investigation techniques, such as dye tracers, hydrograms and groundwater long-term monitoring.

Table 3. Natural Background Level (NBL) and threshold values (TVs) of the arsenic, barium and zinc for the study area.

\begin{tabular}{|c|c|c|c|c|c|c|}
\hline \multirow{2}{*}{ Season } & \multicolumn{2}{|c|}{$\mathrm{As}^{3+}(\mu \mathrm{g} / \mathrm{L})$} & \multicolumn{2}{|c|}{$\mathrm{Ba}^{2+}(\mu \mathrm{g} / \mathrm{L})$} & \multicolumn{2}{|c|}{$\mathrm{Zn}^{2+}(\mu \mathrm{g} / \mathrm{L})$} \\
\hline & Dry & Rainy & Dry & Rainy & Dry & Rainy \\
\hline $\mathrm{REF}^{*}$ & \multicolumn{2}{|c|}{10} & \multicolumn{2}{|c|}{700} & \multicolumn{2}{|c|}{1800} \\
\hline NBL (90\%) & 2.48 & 3.29 & 94.44 & 84.35 & 24.67 & 37.70 \\
\hline NBL (95\%) & 3.03 & 4.05 & 111.17 & 98.98 & 28.48 & 44.47 \\
\hline $\mathrm{TV}($ median + 2* SD) & 3.23 & 4.29 & 115.68 & 102.54 & 43.64 & 27.19 \\
\hline TV (average + 2* SD) & 3.57 & 4.78 & 127.53 & 113.28 & 51.09 & 32.21 \\
\hline No. of samples & 78 & 75 & 78 & 75 & 78 & 75 \\
\hline Minimum & 0.00 & 0.00 & 6.52 & 0.05 & 6.20 & 6.20 \\
\hline Maximum & 10.83 & 12.70 & 301.48 & 255.82 & 132.50 & 58.03 \\
\hline Average & 0.53 & 0.63 & 35.44 & 32.74 & 13.81 & 11.22 \\
\hline Median & 0.19 & 0.14 & 23.59 & 22.00 & 6.36 & 6.20 \\
\hline SD & 1.52 & 2.07 & 46.04 & 40.27 & 18.64 & 10.49 \\
\hline Q1 & 0.11 & 0.06 & 15.19 & 15.10 & 6.20 & 6.20 \\
\hline Q3 & 0.28 & 0.23 & 33.56 & 33.83 & 10.62 & 12.72 \\
\hline
\end{tabular}

REF*: reference according CETESB (2016); SD: standard deviation. 
Table 4. Chemical elements worked, origin, source and seasonal influence in relation to Natural Background Level (NBL) $90 \%$ values.

\begin{tabular}{|c|c|c|c|}
\hline Element & Main origin & Main source & $\begin{array}{l}\text { Seasonal influence } \\
\text { (NBL 90\%) }\end{array}$ \\
\hline $\mathrm{Ca}^{2+}$ & $\begin{array}{l}\text { Geological with } \\
\text { anthropogenic influence }\end{array}$ & Carbonates of Lagoa Santa Member / Mining & A Rainy season \\
\hline $\mathrm{Mg}^{2+}$ & $\begin{array}{l}\text { Geological with } \\
\text { anthropogenic influence }\end{array}$ & Carbonates of Lagoa Santa Member / Mining & $\begin{array}{l}\text { Practically stable slight } \\
\text { increase in rainy season }\end{array}$ \\
\hline $\mathrm{Na}^{+}$ & Geological & $\begin{array}{l}\text { Granite basement and carbonates } \\
\text { of the Pedro Leopoldo Member }\end{array}$ & $\checkmark$ Rainy season \\
\hline $\mathrm{K}^{+}$ & Geological & $\begin{array}{l}\text { Granite basement and carbonates } \\
\text { of the Pedro Leopoldo Member }\end{array}$ & Aainy season \\
\hline $\mathrm{HCO}_{3}^{-}$ & Geological & Carbonates of Lagoa Santa Member & Aainy season \\
\hline $\mathrm{PO}_{4}^{3-}$ & Anthropogenic & $\begin{array}{l}\text { Inadequate dumping of agricultural } \\
\text { and urban waste (sewage) }\end{array}$ & $\checkmark$ Rainy season \\
\hline $\mathrm{SO}_{4}{ }^{2-}$ & Geological & Pyrite and galena interspersed with carbonates & Rainy season \\
\hline $\mathrm{Cl}^{-}$ & Anthropogenic & Agricultural activities & Rainy season \\
\hline $\mathrm{NO}_{3}^{-}$ & Anthropogenic & Agricultural activities & Rainy season \\
\hline $\mathrm{As}^{3+}$ & Geological/Anthropogenic & Carbonates / Inadequate disposal of agricultural pesticides & Rainy season \\
\hline $\mathrm{Ba}^{2+}$ & Geological & $\begin{array}{l}\text { Granite basement and carbonates } \\
\text { of the Pedro Leopoldo Member }\end{array}$ & $\checkmark$ Rainy season \\
\hline $\mathrm{Zn}^{2+}$ & Geological & $\begin{array}{l}\text { Granite basement and carbonates } \\
\text { of the Pedro Leopoldo Member }\end{array}$ & Rainy season \\
\hline
\end{tabular}

\section{ACKNOWLEDGMENTS}

Special thanks go to the Postgraduate Program in Crustal Evolution and Natural Resources of the Geology Department of Universidade Federal de Ouro Preto, the Excursionist and Speleological Society (SEE), the Laboratory of Environmental Geochemistry of the Department of Geology (LGqA-DEGEO) and the Brazilian National Council for Scientific and Technological Development (CNPq - Project n. 141611/2014-6).

\section{REFERENCES}

Agenzia per la Protezione dell'Ambiente e per i Servizi Tecnici, Istituto Superiore di Sanità (APAT-ISS). 2006. Protocollo operativo per la determinazione dei valori di fondo di metalli e metalloidi nei suoli dei siti contaminati. Giugno, APAT-ISS.

Almeida F.F.M. 1977. O cráton do São Francisco. Revista Brasileira de Geociências, 7(4):285-295.

Alvares C.A., Stape J.L., Sentelhas P.C., Gonçalves J.L.M., Sparovek G. 2013. Köppen's climate classification map for Brazil. Meteorologische Zeitschrift, 22(6):711-728. https://dx.doi. org/10.1127/0941-2948/2013/0507

Andreo B., Goldscheider N., Vadillo I., Vías J.M., Neukum C., Sinreich M., Jiménez P., Brechenmacher J., Carrasco F., Hötzl H., Perles M.J., Zwahlen F. 2006. Karst groundwater protection: First application of a Pan-European approach to vulnerability, hazard and risk mapping in the Sierra de Líbar (Southern Spain). Science of Total Environment, 357(1-3):54-73. https://doi.org/10.1016/j. scitotenv.2005.05.019

Andriotti J.L.S. (Ed.). 2010. Interpretação de dados de prospecção geoquímica com o auxílio de estatística. Brasil, CPRM. 73 p.

Appelo C.A.J., Postma D. (Eds.). 2005. Geochemistry Groundwater and Pollution. Balkema, Rotterdam, 649 p.

Aragão F., Menegasse L., Galvão P., Lucon T. 2108. Metodologia para determinação dos níveis naturais de fundo (NBL) e da interpolação de isoconcentrações de parâmetros hidroquímicos. In: Congresso Brasileiro de Águas Subterrâneas, 20., e Encontro Nacional de Perfuradores de Poços, 21. 
Background Criteria for the Identification of Groundwater Thresholds (BRIDGE). 2006. Research for Policy Support. Available at: <http:// nfp-at.eionet.europa.eu/Public/irc/eionet-circle/bridge/library?l=/ public_information/newsletterbridgemay2006p/_EN_1.0_\&a=d>. Accessed on: March 12, 2018.

Background Criteria for the Identification of Groundwater Thresholds (BRIDGE). 2009. Research for Policy Support. Available at: <http:// nfp-at.eionet.europa.eu/Public/irc/eionet-circle/bridge/library?l=/ public_information/newsletterbridgemay2006p/_EN_1.0_\&a=d >. Accessed on: March 12, 2018.

Bolviken B.A. 1971. A statistical approach to the problem of interpretation in geochemical exploration. In: Boyle R.W., McGerrigle J.I. (Eds.), Geochemical Exploration. Canada, Canadian Institution of Mineralogy and Metallurgy, v. 11, p. 564-567.

Brasil. Conselho Nacional do Meio Ambiente. 2008. Resolução Conama No. 396. Diário Oficial da República Federativa do Brasil.

Brasil. Ministério da Saúde. 2011. Portaria No. 2.914. Dispõe sobre os procedimentos de controle e de vigilância da qualidade da água para consumo humano e seu padrão de potabilidade. Diário Oficial da União.

Brasil. Ministério do Meio Ambiente. 2003. Águas subterrâneas. Available at: <www.mma.gov.br>. Accessed on: Dec. 2, 2017.

Canadian Council of Resource and Environmental Ministers (CCREM). 1987. Canadian water quality guidelines. Ottawa, CCREM.

Companhia Ambiental do Estado de São Paulo (CETESB). 2014. Relatório de estabelecimento de valores orientadores para solos e águas subterrâneas no Estado de São Paulo. São Paulo, CETESB, 3 p. Available at: <http://sgw.com.br/cetesb-atualiza-lista-de-valoresorientadores-para-solo-e-aguas-subterraneas.html>. Accessed on: Mar. 16, 2018

Companhia Ambiental do Estado de São Paulo (CETESB). 2016. Valores orientadores para solo e água subterrânea no estado de São Paulo. São Paulo, CETESB, 3 p. Available at: <https://cetesb.sp.gov.br/ aguas-subterraneas/wp-content/uploads/sites/13/2013/11/tabela vos_2016_site.pdf>. Accessed on: Mar. 16, 2018.

Custodio E., Llamas M.R. (Eds.). 2001. Hidrologia subterrânea. Barcelona, Omega, $2350 \mathrm{p}$.

Dardenne M.A. 1978. Síntese sobre a estratigrafia do Grupo Bambuí no Brasil Central. In: Congresso Brasileiro de Geologia, 30., Recife. Anais..., v. 2, p. 597-610.

Dias F.S., Velásques L.N.M. 2002. Hidrogeologia da bacia do rio São Miguel, municípios de Pains and Arcos - MG. Revista Águas Subterrâneas, 1:1-20.

Dias-Oliveira L., Lucon T.N., Costa A.T., Assunção P.H. 2017. Mapeamento hidroquímico para cálcio e magnésio nas águas superficiais e subterrâneas da bacia do rio São Miguel, MG. In: Congresso Brasileiro de Geoquímica, 16., Búzios. Anais..., 5 p.

Dimitrijevic M. 1995. Geology of Yugoslavia. Belgrade, Geoinstitute.

Ducci D., Sellerino M. 2012. Natural background levels for some ions in groundwater of the Campania region (southern Italy). Environmental Earth Sciences, 67(3):683-693. http://dx.doi. org/10.1007/s12665-011-1516-8

Edmunds W.M., Shand P. (Eds.). 2008. Natural groundwater quality. London, Blackwell, 488 p.

Edmunds W.M., Shand P., Hart P., Ward R.S. 2003. The natural (baseline) quality of groundwater: a UK pilot study. Science of Total Environment, 310(1-3):25-35. http://dx.doi.org/10.1016/ S0048-9697(02)00620-4
Feitosa F.A.C., Manoel Filho J., Feitosa E.C., Demetrio J.G.A. (Eds.). 2008. Hidrogeologia: conceitos e aplicações. 3. ed. Rio de Janeiro, CPRM, $812 \mathrm{p}$.

Félix A.A., Freitas Júnior R.L. 2000. Mapeamento Geológico e Hidrogeológico da Bacia do Rio São Miguel, Alto São Francisco, Estado de Minas Gerais. Graduation Project, Universidade Federal de Minas Gerais, Belo Horizonte, 104 p.

Flues M., Hama P., Fornaro A. 2003. Avaliação do nível da vulnerabilidade do solo devido à presença de termelétrica a carvão (Figueira, PR-Brasil). Química Nova, 26(4):479-483. http://dx.doi. org/10.1590/S0100-40422003000400006

Ford D.C., Williams P.W. (Eds.). 2007. Karst Geomorphology and Hidrology. 2. ed. Chichester, NY, Wiley, 562 p.

Forti P. 2002. Speleology in the Third Millennium: achievements and challenges. Theoretical and Applied Kartology, 15:7-26.

Fritzsons E. 2003. Avaliação temporal da qualidade de água como diagnóstico do uso e ocupação das terras na bacia do Alto Capivari, região cárstica curitibana, PR. Thesis, Universidade Federal do Paraná, Curitiba, $190 \mathrm{p}$

Fritzons E., Hindi E.C., Mantovani L.E., Rizzi N.E. 2004. As alterações da qualidade de água do Rio Capivari com o deflúvio: um instrumento de diagnóstico de qualidade ambiental. Engenharia Sanitária e Ambiental, 9(1):239-248

Fritzsons E., Mantovani L.E., Chaves Neto A., Hindi E.C. 2009. A influência das atividades mineradoras na alteração do pH e da alcalinidade em águas fluviais: o exemplo do rio Capivari, região do carste paranaense. Engenharia Sanitária e Ambiental, 14(3):381390. http://dx.doi.org/10.1590/S1413-41522009000300012

Galvão P., Halihan T., Hirata R. 2015. Evaluating karst geotechnical risk in the urbanized area of Sete Lagoas, Minas Gerais, Brazil. Hydrogeology Journal, 23:1499-1513. http://dx.doi.org/10.1007/ s10040-015-1266-x

Galvão P., Halihan T., Hirata R. 2016. The karst permeability scale effect of Sete Lagoas, MG, Brazil. Journal of Hydrology, 532(85):149162. http://dx.doi.org/10.1016/j.jhydrol.2015.11.026

Greenberg A.E., Clesceri L.S., Eaton A.D. 1995. Standard methods for the examination of water and wastewater. 18. ed. Washington, D.C.: American Public Health Association.

Haddad E.A. 2007. Influência antrópica na qualidade da água da bacia hidrográfica do rio São Miguel, carste do alto São Francisco, Minas Gerais. Dissertation, Universidade Federal de Minas Gerais, Belo Horizonte, 156 p.

Haddad E.A., Magalhães Jr. A.P. 2010. Influência antrópica na qualidade da água da bacia hidrográfica do rio São Miguel, carste do alto São Francisco, Minas Gerais. Revista Geosul, 25(49):79-102. https://doi.org/10.5007/2177-5230.2010v25n49p79

Hawkes H.E., Webb J.S. (Eds.). 1962. Geochemistry in mineral exploration. New York, Joanna Cotler Books, 415 p.

Hinsby K., Condesso de Melo M.T., Dahl M. 2008. European case studies supporting the derivation of natural background levels and groundwater threshold values for the protection of dependent ecosystems and human health. Science of Total Environment, 401(1-3):1-20. https://doi.org/10.1016/j.scitotenv.2008.03.018

Instituto Brasileiro de Geografia e Estatística (IBGE). 2003. Base de informações municipais. Rio de Janeiro, IBGE.

Instituto Mineiro de Gestão das Águas (IGAM). 2005. Relatório de monitoramento das águas superficiais na bacia do rio São Francisco em 2004. Belo Horizonte, IGAM, 180 p. 
Istituto Superiore per la Protezione e la Ricerca Ambientale (ISPRA). 2009. Protocollo per la Definizione dei Valori di Fondo per le Sostanze Inorganiche nella Acque Sotterranee. ISPRA. Available at: <http://www.isprambiente.gov.it/files/temi/fondo-metalli-acquesotterranee.pdf>. Accessed on: Feb. 6, 2018.

Kovačič G. 2003. The protection of karst aquifers: the example of the Bistrica Karst Spring (SW Slovenia). Acta Carsologica, 32(2):219-234.

Kovačič G., Ravbar N. 2003. Karst aquifers vulnerability or sensitivity? Acta Carsologica, 32(2):307-314. https://doi. org/10.3986/ac.v32i2.358

Lalehzari R., Tabatabaei S.H., Kholghi M. 2013. Simulation of nitrate transport and wastewater seepage in groundwater flow system. International Journal of Environmental Science and Technology, 10(6):1367-1376. https://doi.org/10.1007/s13762-013-0213-4

Lepeltier C. 1969. A simplified treatment of geochemical data by graphical representation. Economic Geology, 64(5):538-550. https:// doi.org/10.2113/gsecongeo.64.5.538

Matschullat J., Ottenstein R., Reimann C. 2000. Geochemical background - can we calculate it? Environmental Geology 39(9):990-1000. https://doi.org/10.1007/s002549900084

Menegasse L.N., Gonçalves J.M., Fantinel L.M. 2002. Water availability in the karst Province of Arcos-Pains-Doresópolis, Upper São Francisco, Minas Gerais, Brazil. Revista Águas Subterrâneas, 16(1):1-19. https://doi.org/10.14295/ras.v16i1.1297

Meyer B.O. 2018. Petrologia e Geocronologia das fáceis carbonáticas da Formação Sete Lagoas em Pains (MG). Dissertation, Universidade Federal de Ouro Preto, Ouro Preto, 257 p.

Mourão M.A.A., Cruz W.B., Gonçalves R.L.F. 2001. Caracterização Hidrogeológica da Porção Mineira da Bacia Hidrográfica do São Francisco. In: Pinto C.P., Martins-Neto M.A. (Eds.), Bacia do São Francisco Geologia e Recursos Naturais. Belo Horizonte, SBG/MG, p. 327-350.

Müller D., Blum A., Hart A., Hookey J., Kunkel R., Scheidleder A., Tomlin C., Wendland F. 2006. D18: Final proposal for a methodology to set up groundwater threshold values in Europe. BRIDGE. Available at: <http://cordis.europa.eu/result/rcn/51965_en.html>. Accessed on: Mar. 22, 2018.

Pereira D.L. 2018. Avaliação da Vulnerabilidade à contaminação de um Aquífero Cárstico por Adaptação do Método EPIK na Bacia do rio São Miguel, Município de Pains - MG. Graduation Project, Universidade Federal de Ouro Preto, Ouro Preto, 104 p.

Pessoa P.F.P., Loureiro C.O. 2005. Hidrogeologia dos Aqüíferos Cársticos da Região de Lagoa Santa, MG. Thesis, Universidade Federal de Minas Gerais, Belo Horizonte, 356 p.

Piper A.M.A. 1944. Graphic Procedure in the Geochemical Interpretation of Water Analysis. Transactions American Geophysical Union, 25(6):914-928. https://doi.org/10.1029/TR025i006p00914

Pires L.O. 2017. Quimioestratigrafia do endocarste da Gruta do Éden, Pains/MG. Graduation Project, Universidade Federal de Ouro Preto, Ouro Preto, $161 \mathrm{p}$

Reinmann C., Filzmoser P., Garrett R.G. 2005. Background and threshold: critical comparison of methods of determination. Science of the Total Environment, 346(1-3):1-16. http://dx.doi.org/10.1016/j. scitotenv.2004.11.023
Ribeiro A., Paciullo F.V.P., Senra A.S., Valeriano C.M., Trouw R.A.J. 2008. Geologia da Folha Piumhi: SF.23-V-B-II. Escala 1:100.000. Nota explicativa. Minas Gerais, UFRJ/CPRM, 50 p.

Ribeiro J.H., Tuller M.P., Danderfer Filho A. 2003. Projeto Vida Mapeamento Geológico da Região de Sete Lagoas, Pedro Leopoldo, Matosinhos, Lagoa Santa, Vespasiano, Capim Branco, Prudente Morais, Confins e Funilândia - Minas Gerais. Relatório Final. Escala 1:50.000. 2. ed. CPRM, Belo Horizonte, 54 p.

Saadi A. 1991. Ensaio sobre a morfotectônica de Minas Gerais: tensões intraplaca, descontinuidades crustais e morfogênese. Thesis, Universidade Federal de Minas Gerais, Belo Horizonte, 300 p.

Schenone N., Volpedo A.V., Cirelli A.F. 2007. Trace metal contents in water and sediments in Samborombón Bay wetland, Argentina. Wetlands Ecology and Management, 15(4):303-310. http://dx.doi.org/10.1007/s11273-006-9030-6

Serviço Geológico Brasileiro (CPRM). 2012. Bases cartográficas. Available at: <http://www.cprm.gov.br>. Accessed on: Dec. 1, 2017.

Silva R.B.G.D. 1983. Estudo hidroquímico e isotópico das águas subterrâneas do aqüífero Botucatu no Estado de São Paulo. Thesis, Universidade de São Paulo, São Paulo, 156 p.

Sociedade Excursionista e Espeleológica (SEE) (Ed.). 2012. Projeto Arcos Pains de Espeleologia. Ouro Preto, SEE/Universidade Federal de Ouro Preto, 549 p. Available at: <https://see.ufop. $\mathrm{br} /$ sites/default/files/see/files/projeto-arcos-pains-espeleologia. pdf?m=1525724773>. Acessed on: Jan. 20, 2018

Superintendência Regional de Meio Ambiente e Desenvolvimento Sustentável (SUPRAM). 2013. Parecer Único no 1861763/2013. Minas Gerais, SUPRAM.

Tedd K., Coxon C., Misstear B., Daly D., Craig M., Mannix A., Williams T.H. (Eds.). 2017. Assessing and developing Natural Background Levels for chemical parameters in Irish groundwater. Wexford, Environmental Protection Agency, 183 p

Tennant C.B., White M.L. 1959. Study of the distribution of some geochemical data. Economic Geology, 54(7):1281-1290. https://doi. org/10.2113/gsecongeo.54.7.1281

Timo M.B. 2014. Mapeamento geomorfológico da região cárstica do Córrego do Cavalo, Piumhi (MG). Dissertation, Pontifícia Universidade Católica de Minas Gerais, Belo Horizonte, 133 p.

United States Environmental Protection Agency (USEPA). 2017. Water quality standards handbook. USA: Government Institute.

Vázquez-Suñé E., Sánchez-Vila X., Ramirez J.C. 2005. Introductory review of specific factors influencing urban groundwater, an emerging branch of hydrogeology, with reference to Barcelona, Spain. Hydrogeology Journal, 13(3):522-533. http://dx.doi. org/10.1007/s10040-004-0360-2

Villanueva T.C.B., Leal L.R.B., Zucchi M.D.R., Azevedo A.E.G.D., Villanueva P.R. 2014. Caracterização hidroquímica e hidrogeológica do aquífero cárstico Salitre na região de Irecê, Bahia. Revista Brasileira de Recursos Hídricos, 19(4):83-96. http://dx.doi.org/10.21168/rbrh.v19n4.p83-96

Zublena J.P., Cook M.G., St. Clair M.B. (Eds.). 2001. Pollutants in groundwater: health effects. Soil facts (North Carolina Extension Service Publication No. AG-439-14) Available at: <http://ces.soil.ncsu. edu/soilscience/publications/soilfacts>. Acessed on: Mar. 5, 2018. 